\title{
HUBUNGAN SIKAP SOSIAL DAN KECERDASAN EMOSIONAL TERHADAP PRESTASI BELAJAR SISWA SEKOLAH DASAR DI WILAYAH KECAMATAN GUMELAR DI TINJAU DARI GENDER
}

\author{
Armo Armo', Akhmad Jazuli ${ }^{2}$, Tukiran Tanireja ${ }^{3}$ \\ ${ }^{1}$ SDN Karangkemojing, Gumelar, Banyumas \\ ${ }^{2,3}$ Magister Pendidikan Dasar, Universitas Muhammadiyah Purwokerto \\ armoyans79@gmail.com; akhmadjazuli@ump.ac.id; tukiran@ump.ac.id
}

\begin{abstract}
This study aims to determine the relationship between (1) social attitudes and learning achievements of fifth grade elementary school students in the Nagawiru Cluster Gumelar District; (2) emotional intelligence with learning achievement of fifth grade elementary school students; and (3) social attitudes and emotional intelligence of fifth grade elementary school students.This research used a correlational research with a quantitative approach. The variables in this study are emotional intelligence, social attitudes, and student achievement. The study population was all fifth grade students in elementary schools in the Nagawiru cluster. The number of samples taken was 75 students by using proportional random sampling technique. Data collection techniques using questionnaires and documentary studies. The analysis technique used is the product moment correlation technique and multiple regression. The results showed that (1) there was a positive and significant relationship between social attitudes with class $V$ student achievement Whereas female students have a positive and significant relationship between social attitudes and learning achievements ; (2) there a positive and significant relationship between emotional intelligence and student achievemen especially females; and (3) there is a positive and significant relationship between social attitudes and emotional intelligence. Meanwhile, both male and female students have social attitudes with emotional intelligence with low and moderate categories.
\end{abstract}

Keywords: social attitude, emotional quotient, achievement of elementary student'

Abstrak. Penelitian ini bertujuan untuk mengetahui hubungan antara (1) sikap sosial dengan prestasi belajar siswa kelas V SD se-Gugus Nagawiru Kecamatan Gumelar; (2) kecerdasan emosional dengan prestasi belajar siswa kelas V SD se-Gugus Nagawiru Kecamatan Gumelar; (3) sikap sosial dengan kecerdasan emosional siswa kelas V SD se-Gugus Nagawiru Kecamatan Gumelar. Penelitian ini merupakan penelitian korelasional dengan pendekatan kuantitatif. Variabel dalam penelitian ini adalah kecerdasan emosional, sikap sosial, dan prestasi belajar siswa. Populasi penelitian ini adalah semua siswa kelas V di SD se-Gugus Nagawiru. Jumlah sampel yang diambil sebanyak 75 siswa dengan menggunakan teknik proportional random sampling. Teknik pengumpulan data menggunakan angket dan studi dokumenter. Teknik analisis yang digunakan adalah teknik korelasi Product Moment dan Regresi Ganda. Hasil penelitian menunjukkan bahwa (1) terdapat hubungan positif dan signifikan antara sikap sosial dengan prestasi belajar siswa kelas V khususnya siswa perempuan; (2) terdapat hubungan positif dan signifikan antara kecerdasan emosional dengan prestasi belajar siswa kelas V khususnya siswa perempuan; dan (3) terdapat hubungan yang positif antara sikap sosial dan kecerdasan emosional secara bersama-sama dengan prestasi belajar siswa kelas V khususnya pada siswa perempuan.

Kata Kunci : sikap sosial, kecerdasan emosional siswa SD 


\section{Latar Belakang Masalah}

Tujuan pendidikan tidak hanya memperhatikan aspek pengetahuan saja, tetapi membangun individu yang memiliki aspek kepribadian yang baik. Tujuan pendidikan nasional erat kaitannya dengan potensi peserta didik seperti pengetahuan, keterampilan, sikap dan kepribadian peserta didik. Teori Bloom menyatakan bahwa bentuk perilaku harus dirumuskan dalam tujuan pendidikan yang terbagi menjadi tiga bidang, yaitu : bidang kognitif, afektif, dan psikomotorik. Bidang kognitif berhubungan dengan kemampuan intelektual, domain afektif berkenaan dengan sikap, nilai-nilai dan apresiasi, serta domain psikomotorik yang meliputi semua tingkah laku yang menggunakan syaraf dan otot badan. (Wina, 2008).

Pendidikan mengajarkan individu tentang nilai-nilai maupun norma-norma yang berlaku dimasyarakat sebagai pegangan dalam mengatur tingkah laku. Seiring berjalannya waktu, perkembangan teknologi dan informasi sangat berpengaruh terhadap berbagai sektor seperti : informasi, komunikasi, budaya, politik, ekonomi, dan pendidikan. Perkembangan inilah yang kita kenal dengan istilah arus globalisasi. Setiap individu harus kritis dalam menimbang segala sesuatu yang masuk. Melalui perkembangan teknologi dan informasi banyak pelajar terbawa arus negatif dari globalisasi. Mereka cenderung berperilaku menyimpang dari norma-norma yang berlaku di masyarakat, seperti perilaku individualis hingga perilaku anarkis. Berakar dari hal tersebut peran pendidikan menjadi cukup vital dalam membentuk pribadi yang baik.

Masyarakat beranggapan bahwa prestasi belajar di sekolah menentukan kesuksesan seseorang. Hal ini dapat dilihat dari berbagai upaya orang tua yang mengikut-sertakan anaknya pada bimbingan belajar di luar sekolah agar memperoleh prestasi belajar yang memuaskan. Padahal prestasi belajar ditentukan oleh berbagai hal yang kompleks dan tidak hanya ditentukan dari pengetahuan saja, diantaranya adalah kecerdasan emosional dan sikap sosial. Siswa yang mampu mengendalikan emosi umumnya memiliki prestasi belajar yang tinggi. Siswa juga harus dapat memotivasi diri, mengendalikan diri dan dapat menjalin hubungan dengan baik atau bersosialisasi dengan teman maupun gurunya. Peneliti tertarik untuk mengetahui hubungan antara sikap sosial dan kecerdasan emosional dengan prestasi belajar siswa sekolah dasar di wilayah Kecamatan Gumelar ditinjau dari gender.

\section{Sikap Sosial}

Sikap sosial merujuk pada predisposisi, sikap (kecenderungan berbuat atau tidak berbuat dalam situasi tersedia) yang dimiliki bersama dengan sejumlah orang-orang lain yang sama keyakinan, nilai-nilai ideologi atau orientasi (Andi Appiare, A.T, 2006: 308). Suatu sikap sosial dinyatakan oleh cara-cara kegiatan yang sama dan berulang-ulang terhadap suatu objek sosial dan dinyatakan tidak hanya oleh seseorang saja melainkan oleh sekelompok orang atau masyarakat. (Gerungan, 2004: 161-162).

Sikap sosial merupakan satu predisposisi atau kecenderungan untuk bertingkah laku dengan satu cara yang terarah kepada tujuan-tujuan sosial, sebagai lawan dari sikap yang terarah kepada tujuan-tujuan pribadi. (Chalpin, 2000: 469).

Sikap sosial adalah kesadaran individu yang mementukan perbuatan nyata dan berulang ulang terhadap objek sosial. Sikap sosial ini dinyatakan oleh seorang tapi diperhatikan oleh sekelompoknya. (Abu, 2009: 152). Sikap sosial dinyatakan tidak hanya oleh seseorang saja tetapi diperhatikan oleh orang-orang sekelompoknya dan terjadi secara berulang-ulang. (Siti, 1973: 40). 
Sikap sosial merupakan kesadaran seseorang untuk bertingkah laku dengan cara tertentu dan di lingkungan tertentu terhadap objek sosial. Sikap ini juga tidak hanya dinyatakan oleh diri sendiri melainkan juga diperhatikan dan dinyatakan oleh orang di lingkungannya.Sikap sosial akan terlihat ketika seseorang sedang melakukan interaksi dengan lingkungan sekitarnya. Sikap sosial tercermin dengan perilaku jujur, disiplin, tanggung jawab, peduli, santun, responsif dan proaktif, dan menunjukan sikap sebagai bagian dari solusi atas berbagai permasalahan.

\section{Kecerdasan Emosional}

Kecerdasan emosional adalah kemampuan memantau dan mengendalikan persaaan sendiri dan orang lain, serta menggunakan perasaanperasaan itu untuk memandu pikiran dan tindakan. (Goleman, 2003: 513). Kecerdasan emosional merujuk pada kemampuan mengenai perasaan sendiri dan perasaan orang lain, memotivasi diri sendiri, dan kemampuan mengelola emosi dengan baik pada diri sendiri serta dalam hubungan dengan orang lain. (Goleman, 2003: 512).

Kecerdasan emosional adalah kemampuan merasakan, memahami, dan secara aktif menerapkan daya dan kepekaan emosi sebagai sumber emosi serta pengaruh yang manusiawi. Kecerdasan emosi menuntut pemilikan perasaan, belajar mengakui, menghargai perasaan pada diri sendiri atau orang lain serta menanggapinya dengan tepat (Asrori, 2009: 26).

Kecerdasan emosional lebih merujuk pada kemampuan-kemampuan mengendalikan diri, memotivasi diri, dan berempati. Adapun aspek-aspek dalam kecerdasan emosional diantaranya adalah : (1) kesadaran diri; (2) mengelola emosi; (3) memanfaatkan emosi secara produktif; (4) empati; dan (5) membina hubungan (Yusuf, 2007: 113).

Secara umum kecerdasan emosi dapat diartikan sebagai kemampuan yang mencakup tindakan mengenali dan memantau perasaan diri sendiri atau orang lain, pengendalian diri, memotivasi diri, mampu membaca dan menghadapi perasaan orang lain dengan efektif, mampu mengelola emosi sehingga dapat dijadikan dorongan untuk menjadi lebih produktif dan membimbing tindakan lebih terarah, serta mampu membina hubungan baik dengan orang lain.

\section{Prestasi Belajar}

Prestasi belajar adalah hasil yang telah dicapai (dari yang dilakukan atau dikerjakan dan sebagainya). Prestasi belajar adalah pengasaan pengetahuan atau keterampilan yang dikembangkan oleh mata pelajaran, biasanya ditunjukan dengan nilai tes atau nilai berupa angka yang diberikan oleh guru. (KBBI, 2005: 787).

Prestasi belajar merupakan hasil pengukuran dan penilaian usaha belajar yang dinyatakan dalam bentuk simbol, huruf maupun kalimat yang menceritakan hasil yang sudah dicapai oleh setiap siswa pada periode tertentu (Abu, 2010: 14). Secara umum dari pemaparan di atas dapat disimpulkan bahwa prestasi belajar adalah hasil yang diperoleh siswa melalui usaha yang berupa kemampuan dalam mencapai pengetahuan, sikap, dan ketermpilan yang diukur dengan tes dan non-tes serta biasanya dinyatakan dalam bentuk angka atau skor.

\section{Gender}

Gender merupakan sifat-sifat yang melekat dan dimiliki seseorang, baik secara psikologis maupun sosiokultural, sebagai pembeda antara laki-laki dan perempuan. Hal ini berbeda dengan jenis kelamin, dimana gender dapat dipertukarkan dan dapat diubah. Identitas gender atau perasaan seseorang baik sebagai laki-laki ataupun perempuan akan dicapai ketika anak berumur usia 3 tahun. 
Aturan-aturan yang berlaku di masyarakat menggambarkan dan menegaskan bahwa seharusnya laki-laki dan perempuan bertindak, berfikir dan merasa disebut sebagai peran gender. Masyarakat gender telah diklasifikasikan ataupun dibedakan satu dengan lainnya. Perbedaan gender adalah perbedaan perilaku atau psikososial antara laki-laki dan perempuan, berbeda dari perbedaan jenis kelamin, yaitu perbedaan fisik antar pria dan wanita. Perbedaannya dapat diukur baik fisik maupun perilaku antara bayi laki-laki dan perempuan sangat sedikit seperti pada teori citra dalam komunikasi perusahaan.

Penyebab terjadinya perbedaan gender salah satunya pengalaman dan harapan anak laki-laki dan perempuan berkaitan dengan 3 hal dari identitas gender yakni; Peran Gender, yakni perilaku, keinginan, sikap, keterampilan, serta kepribadian ketika budaya mempertimbangkan kesesuaian untuk perbedaan laki-laki atau perempuan. Misalnya, dalam sebuah budaya perempuan diharapkan meluangkan banyak waktu untuk mengurus rumah tangga dan anak sedangkan laki-laki menyediakan kebutuhan rumah tangga; Tipe Geder, merupakan pelaksanaan dari peran gender, yang mana dalam tipe gender orang tua sangat besar pengaruhnya seperti yang dilakukan orang barat pada masa awal kanak-kanak kebanyakan ayah berkomunikasi dengan anak laki-laki sedangkan seorang ibu banyak berkomunikasi dengan anak perempuan. Dari sikap orang tua itulah terjadilah pembentukan gender; Stereotipe Gender, yakni generalisasi prasangka tentang perilaku laki-laki atau perempuan, dimana semua perempuan itu cenderung pasif dan tergantung sedangkan semua laki-laki cenderung aktif dan mandiri.

\section{METODE PENELITIAN}

Penelitian dilaksanakan di empat sekolah dasar di Gugus Nagawiru wilayah Kecamatan Gumelar, Kabupaten Banyumas. Penelitian ini menggunakan pendekatan kuantitatif, karena data hasil penelitian diukur dan dikonversikan dalam bentuk angka-angka dan dianalisis dengan teknik statistic.

Subyek penelitian ini adalah siswa kelas V sekolah dasar di Gugus Nagawiru wilayah Kecamatan Gumelar, Kabupaten Banyumas tahun ajaran 2018/2019. Sampel secara sederhana adalah sebagian dari populasi yang terpilih dan mewakili populasi tersebut (Yusuf, 2014: 150). Pengambilan sampel dalam penelitian ini menggunakan teknik proportional random sampling. Alasan penggunaan proportional randomsampling adalah untuk memberikan peluang yang sama bagi setiap anggota populasi untuk dipilih sebagai sampel.

Tabel 1. Distribusi Sampel Penelitian Setiap Sekolah

\begin{tabular}{|c|c|c|}
\hline Sekolah Dasar & $\begin{array}{c}\text { Perhitungan Jumlah } \\
\text { Sampel }\end{array}$ & Jumlah Sampel \\
\hline SDN 2 Karangkemojing & $\mathrm{n}=\frac{22}{90} \times 75=18,5$ & 19 \\
\hline SDN 2 Paningkaban & $\mathrm{n}=\frac{24}{90} \times 75=20$ & 20 \\
\hline SDN 5 Cihonje & $\mathrm{n}=\frac{21}{90} \times 75=17,5$ & 18 \\
\hline SDN 1 Paningkaban & $\mathrm{n}=\frac{23}{90} \times 75=19,1$ & 75 \\
\hline \multicolumn{2}{|c|}{ Jumlah } \\
\hline
\end{tabular}


Variabel dalam penelitian ini terdiri dari variabel bebas (independent) dan variabel terikat (dependent). Variabel bebas dalam penelitian ini ada dua yaitu: sikap sosial $\left(\mathrm{X}_{1}\right)$, dan kecerdasan emosional $\left(\mathrm{X}_{2}\right)$. Sedangkan variabel terikatnya adalah hasil belajar siswa kelas V SD gugus Nagawiru Korwilcam Dindik Kecamatan Gumelar tahun pelajaran 2018/2019 (Y). Pada penelitian ini, pengumpulan data dilakukan dengan menggunakan dokumentasi dan angket.

Observasi dalam penelitian ini digunakan sebagai studi pendahuluan dengan beberapa siswa SD di gugus Nagawiru Korwilcam Dindik Gumelar. Instrumen yang akan digunakan dalam penelitian ini adalah angket yang berbentuk checklist yaitu responden hanya perlu memberi tanda $(\sqrt{ })$ kedalam item-item yang sesuai keadaan sebenarnya. Pernyataan daalam angket

\section{HASIL PENELITIAN DAN PEMBAHASAN \\ 1. Hubungan Sikap Sosial dengan Prestasi Belajar Siswa}

Terdapat hubungan yang positif dan signifikan antara sikap sosial $\left(\mathrm{X}_{1}\right)$ dengan hasil prestasi belajar siswa kelas $\mathrm{V}(\mathrm{Y})$ dengan nilai $\rho<0,05$ yaitu 0,007 $<0,05$ sehingga hipotesis pertama "Terdapat hubungan positif dan signifikan antara sikap sosial dengan prestasi belajar siswa SD se-gugus Nagawiru Kecamatan Gumelar", diterima. Sedangkan determinasi sikap sosial $\left(\mathrm{X}_{1}\right)$ dengan hasil prestasi belajar siswa (Y) sebesar 9,5\%. Hal ini menunjukkan bahwa sikap sosial siswa kelas V sekolah dasar se Gugus Nagawiru tahun ajaran 2018/2019 berada pada kategori rendah.

\section{Hubungan Kecerdasan Emosional dengan Prestasi Belajar Siswa}

Terdapat hubungan yang posistif dan signifikan antara kecerdasan emosional ada yang berupa positif dan ada yang negatif. Hal tersebut dimaksudkan agar siswa benar-benar berfikir untuk memilih responden yang sesuai.

Dokumentasi digunakan untuk mengungkap prestasi belajar siswa. Peneliti menggunakan data nilai hasil belajar (rapor) siswa kelas V Semester I SD se-Gugus Nagawiru Kecamatan Gumelar Tahun Pelajaran 2018/2019.

Analisis deskriptif dipilih dikarenakan dalam penelitian ini dilakukan untuk populasi tanpa diambil sampelnya dan pada penelitian ini digunakan untuk mencari kuatnya hubungan antara variabel melalui analisis korelasi. Hal ini juga diperlukan untuk menentukan kecenderungan hasil penilaian dari angket dan prestasi belajar siswa, maka dilakukan dengan membandingkan nilai rata-rata observasi dengan konversi kategori pada kurva normal ideal

$\left(\mathrm{X}_{2}\right)$ dengan hasil prestasi belajar siswa kelas $\mathrm{V}(\mathrm{Y})$ dengan nilai $\rho<0,05$ yaitu $0,000<0,05$ sehingga hipotesis kedua "Terdapat hubungan positif dan signifikan antara kecerdasan emosional dengan prestasi belajar siswa SD segugus Nagawiru Kecamatan Gumelar" diterima. Sedangkan determinasi kecerdasan emosional $\left(\mathrm{X}_{2}\right)$ dengan hasil prestasi belajar siswa (Y) sebesar 19,8\%. Hal ini menunjukkan bahwa kecerdasan emosional siswa kelas V sekolah dasar se Gugus Nagawiru tahun ajaran 2018/2019 berada pada kategori rendah.

\section{Hubungan Sikap Sosial dengan Kecerdasan Emosional}

Terdapat hubungan yang posistif dan signifikan antara sikap sosial $\left(\mathrm{X}_{1}\right)$ dengan kecerdasan emosional siswa kelas $\mathrm{V}\left(\mathrm{X}_{2}\right)$ dengan nilai $\rho<0,05$ yaitu $0,000<0,05$ sehingga hipotesis ketiga "Terdapat hubungan positif dan signifikan sikap sosial dengan kecerdasan emosional siswa SD SeGugus Nagawiru Kecamatan Gumelar" 
diterima. Hal ini menunjukkan bahwa sikap social siswa kelas V sekolah dasar mempengaruhi tingkat kecerdasan emosional siswa se Gugus Nagawiru tahun ajaran 2018/2019.

\section{Hubungan antara Sikap Sosial dan Kecerdasan Emosional dengan Prestasi Belajar Siswa SD se-gugus Nagawiru Kecamatan Gumelar}

Terdapat hubungan yang posistif dan signifikan antara sikap sosial $\left(\mathrm{X}_{1}\right)$ dan kecerdasan emosional $\left(\mathrm{X}_{2}\right)$ terhadap hasil prestasi belajar siswa kelas $\mathrm{V}(\mathrm{Y})$ dengan nilai $\rho>0,05$ yaitu $0,060<0,05$ sehingga hipotesis keempat "Terdapat hubungan positif dan signifikan antara Sikap Sosial dan Kecerdasan Emosional dengan Prestasi Belajar Siswa SD seGugus Nagawiru Kecamatan Gumelar" diterima. Sedangkan determinasi sikap sosial $\left(\mathrm{X}_{1}\right)$ dan kecerdasan emosional siswa $\left(\mathrm{X}_{2}\right)$ dengan hasil prestasi belajar siswa (Y) sebesar 20,3\%. Hal ini menunjukkan bahwa sikap sosial dan kecerdasan emosional siswa kelas V sekolah dasar se Gugus Nagawiru tahun ajaran 2018/2019 berada pada kategori cukup.

\section{Klasifikasi Berdasarkan Gender Siswa Laki-Laki}

5.1. Hubungan Sikap Sosial dengan Prestasi Belajar Siswa

Tidak terdapat hubungan yang posistif dan signifikan antara sikap sosial $\left(\mathrm{X}_{1}\right)$ dengan hasil prestasi belajar siswa kelas $\mathrm{V}(\mathrm{Y})$ dengan nilai $\rho>0,05$ yaitu 0,328 $>0,05$ sehingga hipotesis pertama "Terdapat hubungan positif dan signifikan antara sikap sosial dengan prestasi belajar siswa laki-laki kelas $\mathrm{V}$ SD se-gugus Nagawiru Kecamatan Gumelar", ditolak. Sedangkan determinasi sikap sosial $\left(\mathrm{X}_{1}\right)$ dengan hasil prestasi belajar siswa (Y) sebesar 16,3\%. Hal ini menunjukkan bahwa sikap sosial siswa kelas V sekolah dasar se Gugus Nagawiru tahun ajaran 2018/2019 berada pada kategori rendah.
5.2. Hubungan Kecerdasan Emosional dengan Prestasi Belajar Siswa

Tidak terdapat hubungan yang posistif dan signifikan antara kecerdasan emosional $\left(\mathrm{X}_{2}\right)$ dengan hasil prestasi belajar siswa laki-laki kelas V (Y) dengan nilai $\rho>0,05$ yaitu $0,849>0,05$ sehingga hipotesis kedua "Terdapat hubungan positif dan signifikan antara kecerdasan emosional dengan prestasi belajar siswa laki-laki kelas V SD segugus Nagawiru Kecamatan Gumelar" diterima. Sedangkan determinasi kecerdasan emosional $\left(\mathrm{X}_{2}\right)$ dengan hasil prestasi belajar siswa (Y) sebesar $0,1 \%$. Hal ini menunjukkan bahwa kecerdasan emosional siswa laki-laki kelas V sekolah dasar se Gugus Nagawiru tahun ajaran 2018/2019 berada pada kategori sangat rendah.

5.3. Hubungan Sikap Sosial dengan Kecerdasan Emosional

Terdapat hubungan yang posistif dan signifikan antara sikap sosial $\left(\mathrm{X}_{1}\right)$ dengan kecerdasan emosional siswa kelas $\mathrm{V}\left(\mathrm{X}_{2}\right)$ dengan nilai $\rho<0,05$ yaitu $0,028<0,05$ sehingga hipotesis ketiga "Terdapat hubungan positif dan signifikan sikap sosial dengan kecerdasan emosional siswa laki-laki kelas V SD Se-Gugus Nagawiru Kecamatan Gumelar" diterima. Hal ini menunjukkan bahwa terdapat hubungan antara sikap sosial dan kecerdasan emosional siswa laki-laki kelas V sekolah dasar se-Gugus Nagawiru tahun ajaran 2018/2019.

5.4. Hubungan antara Sikap Sosial dan Kecerdasan Emosional dengan Prestasi Belajar Siswa SD se-gugus Nagawiru Kecamatan Gumelar

Terdapat hubungan yang posistif dan signifikan antara sikap sosial $\left(\mathrm{X}_{1}\right)$ dan kecerdasan emosional $\left(\mathrm{X}_{2}\right)$ terhadap hasil prestasi belajar siswa laki-laki kelas $\mathrm{V}(\mathrm{Y})$ dengan nilai $\rho>0,05$ yaitu 0,615 $>0,05$ sehingga hipotesis keempat "Terdapat hubungan positif dan signifikan antara Sikap Sosial dan Kecerdasan Emosional dengan Prestasi 


\section{Armo Armo, Akhmad Jazuli dan Tukiran Tanireja}

Belajar Siswa Laki-Laki SD se-Gugus Nagawiru Kecamatan Gumelar" diterima. Sedangkan determinasi sikap sosial $\left(\mathrm{X}_{1}\right)$ dan kecerdasan emosional siswa $\left(\mathrm{X}_{2}\right)$ dengan hasil prestasi belajar siswa (Y) sebesar 2,7\%. Hal ini menunjukkan bahwa sikap sosial dan kecerdasan emosional siswa kelas V sekolah dasar se Gugus Nagawiru tahun ajaran 2018/2019 berada pada kategori sangat rendah.

\section{Siswa Perempuan}

6.1. Hubungan Sikap Sosial dengan Prestasi Belajar Siswa

Tidak terdapat hubungan yang posistif dan signifikan antara sikap sosial $\left(\mathrm{X}_{1}\right)$ dengan hasil prestasi belajar siswa kelas $\mathrm{V}(\mathrm{Y})$ dengan nilai $\rho<0,05$ yaitu 0,039 $<0,05$ sehingga hipotesis pertama "Terdapat hubungan positif dan signifikan antara sikap sosial dengan prestasi belajar siswa perempuan kelas $\mathrm{V}$ SD se-gugus Nagawiru Kecamatan Gumelar", diterima. Sedangkan determinasi sikap sosial $\left(\mathrm{X}_{1}\right)$ dengan hasil prestasi belajar siswa $(\mathrm{Y})$ sebesar 11,6\%. Hal ini menunjukkan bahwa sikap sosial siswa kelas V sekolah dasar se Gugus Nagawiru tahun ajaran 2018/2019 berada pada kategori rendah.

6.2. Hubungan Kecerdasan Emosional dengan Prestasi Belajar Siswa

Tidak terdapat hubungan yang posistif dan signifikan antara kecerdasan emosional $\left(\mathrm{X}_{2}\right)$ dengan hasil prestasi belajar siswa laki-laki kelas V (Y) dengan nilai $\rho<0,05$ yaitu $0,023<0,05$ sehingga hipotesis kedua "Terdapat hubungan positif dan signifikan antara kecerdasan emosional dengan prestasi belajar siswa perempuan kelas V SD segugus Nagawiru Kecamatan Gumelar" diterima. Sedangkan determinasi kecerdasan emosional $\left(\mathrm{X}_{2}\right)$ dengan hasil prestasi belajar siswa (Y) sebesar 13,8\%. Hal ini menunjukkan bahwa kecerdasan emosional siswa perempuan kelas $\mathrm{V}$ sekolah dasar se Gugus Nagawiru tahun ajaran 2018/2019 berada pada kategori sangat rendah.
6.3. Hubungan Sikap Sosial dengan Kecerdasan Emosional

Terdapat hubungan yang posistif dan signifikan antara sikap sosial $\left(\mathrm{X}_{1}\right)$ dengan kecerdasan emosional siswa kelas $\mathrm{V}\left(\mathrm{X}_{2}\right)$ dengan nilai $\rho<0,05$ yaitu $0,000<0,05$ sehingga hipotesis ketiga "Terdapat hubungan positif dan signifikan sikap sosial dengan kecerdasan emosional siswa perempuan kelas V SD Se-Gugus Nagawiru Kecamatan Gumelar" diterima. Hal ini menunjukkan bahwa terdapat hubungan yang baik antara sikap sosial dan kecerdasan emosional siswa perempuan kelas V sekolah dasar se-Gugus Nagawiru tahun ajaran 2018/2019.

6.4. Hubungan antara Sikap Sosial dan Kecerdasan Emosional dengan Prestasi Belajar Siswa SD se-gugus Nagawiru Kecamatan Gumelar

Terdapat hubungan yang posistif dan signifikan antara sikap sosial $\left(\mathrm{X}_{1}\right)$ dan kecerdasan emosional $\left(\mathrm{X}_{2}\right)$ terhadap hasil prestasi belajar siswa laki-laki kelas $\mathrm{V}(\mathrm{Y})$ dengan nilai $\rho>0,05$ yaitu 0,062 $>0,05$ sehingga hipotesis keempat "Terdapat hubungan positif dan signifikan antara Sikap Sosial dan Kecerdasan Emosional dengan Prestasi Belajar Siswa Perempuan SD se-Gugus Nagawiru Kecamatan Gumelar" diterima. Sedangkan determinasi sikap sosial $\left(\mathrm{X}_{1}\right)$ dan kecerdasan emosional siswa $\left(\mathrm{X}_{2}\right)$ dengan hasil prestasi belajar siswa perempuan (Y) sebesar $15,1 \%$. Hal ini menunjukkan bahwa sikap sosial dan kecerdasan emosional siswa kelas V sekolah dasar se Gugus Nagawiru tahun ajaran 2018/2019 berada pada kategori rendah.

Berdasarkan hasil uji hipotesis, diperkuat dengan kajian teori tentang hubungan sikap sosial dan kecerdasan emosional dengan prestasi belajar siswa kelas V SD se-Gugus Nagawiru Kecamatan Gumelar Tahun Pelajaran 2018/2019 jika di tinjau dari gender adalah sebagai berikut :

\section{Sikap Sosial}


Sikap sosial membantu siswa dalam memulai hubungan dengan teman sebayanya di kelas. Hubungan antar murid-murid dan guru-murid akan terjalin lebih baik jika memiliki sikap sosial. Hubungan antar siswa dan guru yang terjadi lebih dapat membantu siswa mendapatkan pengetahuan yang lebih luas atau lebih tinggi. Sikap sosial dinyatakan oleh cara-cara kegiatan yang sama dan berulang-ulang terhadap suatu objek sosial dan dinyatakan tidak hanya oleh seorang saja melainkan oleh sekelompok orang atau masyarakat. Objek sosial dalam penelitian ini adalah berkaitan tentang peraturan sekolah, interaksi dengan teman sebaya, dan tugas-tugas yang diberikan dari guru. Siswa yang memiliki sikap sosial yang baik akan tercermin dalam perilaku peduli, tanggung jawab, disiplin, dan jujur terhadap kewajibannya. Gerungan (2004: 161-162). Individu yang memiliki kemampuan empati lebih mampu menangkap sinyal-sinyal sosial yang tersembunyi yang mengisyaratkan apa yang dibutuhkan orang lain, sehingga ia lebih mampu menerima sudut pandang orang lain, peka terhadap perasaan orang lain, dan lebih mampu untuk mendengarkan orang lain. (Goleman, 2003).

Sikap sosial merupakan kesadaran seseorang untuk bertingkah laku dengan cara tertentu dan di lingkungan tertentu terhadap objek sosial (Chaplin, 2000: 469). Sikap ini juga tidak hanya dinyatakan oleh diri sendiri melainkan juga diperhatikan dan dinyatakan oleh orang di lingkungannya. Sikap sosial akan terlihat ketika seseorang sedang melakukan interaksi dengan lingkungan sekitarnya. Siswa yang memiliki sikap sosial yang baik akan tercermin dalam perilaku peduli, tanggung jawab, disiplin, dan jujur terhadap kewajibannya. Perilaku tersebut akan mendorong siswa untuk lebih berprestasi.
Proses belajar yang baik akan meningkatkan kemampuan belajar dan prestasi belajar siswa. Siswa yang memiliki sikap sosial yang baik dapat cepat memahami maksud guru dan lebih cepat menangkap pelajarannya. Tak dapat dipungkiri, sikap sosial membantu meningkatkan prestasi belajar siswa. Semakin baik sikap sosial, semakin tinggi determinasinya terhadap preatsi belajar siswa.

\section{Kecerdasan Emosional}

Kecerdasan emosional merujuk pada kemampuan mengenali perasaan sendiri dan perasaan orang lain, memotivasi diri sendiri, dan kemampuan mengelola emosi dengan baik pada diri sendiri serta dalam hubungan dengan orang lain. (Goleman , 2003: 512). Jadi, kecerdasan emosional juga memberikan kontribusi terhadap prestasi belajar siswa. Siswa yang mengenali emosi diri dan mampu mengelola emosi pada dirinya, mereka akan mampu memotivasi diri untuk meraih hasil terbaik dalam belajar dan tidak mudah putus asa memaksimalkan potensi dirinya. Artinya, apabila seseorang siswa mempunyai kecerdasan emosional yang baik maka pretasi belajar siswa tersebut menjadi baik pula. Sejalan dengan hal tersebut "individu yang memiliki tingkat kecerdasan emosional yang labih baik, dapat menjadi lebih terampil dalam menenangkan dirinya dengan cepat, dan lebih terampil dalam memusatkan perhatian, dalam berhubungan dengan orang lain, dan cakap dalam memahami orang lain serta dapat untuk kerja akademis di sekolah dengan baik. Keterampilan dasar emosional tidak dapat dimiliki secara tiba-tiba, tetapi membantu proses dalam waktu yang lama untuk mempelajarinya, dan pengaruh lingkungan dapat membentuk kecerdasan emosional yang besar.

Hal positif akan diperoleh bila anak diajarkan keterampilan dasar kecerdasan emosional, secara emosional akan lebih cerdas, penuh pengertian, 
mudah menerima perasaan-perasaan dan lebih banyak pengalaman dalam memecahkan permasalahannya sendiri, sehingga pada saat remaja akan lebih banyak sukses disekolah dan dalam berhubungan dengan rekan-rekan sebaya serta akan terlindung dari resiko-resiko seperti obat terlarang, kenakalan, kekerasan serta seks yang tidak aman (Gottman, 2001 : 250).

Kecerdasan emosional adalah salah satu faktor yang penting yang harus dimiliki siswa untuk memenuhi kebutuhan dalam meraih prestasi belajar yang lebih baik di sekolah. Siswa yang mempunyai kecerdasan emosional yang tinggi akan memiliki kemampuan yang baik terhadap preatsi belajar. Demikian pula sebaliknya, seorang siswa yang mempunyai kecerdasan emosional yang rendah akan cenderung mengalami kesulitan untuk berpretasi. Pada akhirnya akan berdampak pada kesulitan menerima pelajaran dan turunnya nilai akhir pelajaran.

\section{Prestasi Belajar}

Prestasi belajar dalam penelitian ini mengacu pada rata-rata nilai rapor kelas V semester 1 tahun ajaran 2018/2019 yang terdiri atas delapan mata pelajaran yaitu Pendidikan Agama, PPKN, Bahasa Indonesia, Matematika, IPA, IPS, Senibuda dan Keterampilan, Pendidikan Jasmani, Bahasa Jawa, dan Budaya Banyumasan. Prestasi belajar menurut Abudi Riyanto (2010) adalah hasil pengukuran dari penilaian usaha belajar yang dinyatakan dalam bentuk simbol, huruf maupun kalimat yang mencerminkan hasil yang sudah dicapai oleh setiap siswa dalam periode tertentu. Prestasi belajar dipengaruhi oleh berbagai faktor, dua diantaranya adalah sikap sosial siswa dan kecerdasan emosional.

Dengan demikian, hubungan sikap sosial yang tinggi dan kecerdasan emosional yang baik maka akan berdampak pada prestasi belajar siswa yang meningkat. Penelitian yang telah dilakukan dapat disimpulkan secara umum bahwa terdapat hubungan positif dan signifikan antara sikap sosial dan kecerdasan emosional dengan prestasi belajar siswa kelas V Sekolah Dasar Gugus Nagawiru Kecamatan Gumelar Kabupaten Banyumas Tahun Pelajaran 2018/2019 ditunjau dari gender..

\section{KESIMPULAN}

Beberapa simpulan yang diambil dari penelitian adalah: (1) terdapat hubungan yang posistif dan signifikan antara sikap sosial dengan hasil prestasi belajar siswa kelas V Sekolah Dasar Gugus Nagawiru Kecamatan Gumelar Kabupaten Banyumas; (2) terdapat hubungan yang positif dan signifikan antara kecerdasan emosional dengan hasil prestasi belajar siswa kelas V Sekolah Dasar Gugus Nagawiru Kecamatan Gumelar Kabupaten Banyumas. Kecerdasan emosional siswa kelas V sekolah dasar se Gugus Nagawiru tahun ajaran 2018/2019 berada pada kategori rendah; (3) terdapat hubungan yang positif dan signifikan antara sikap sosial dan kecerdasan emosional terhadap hasil prestasi belajar siswa kelas $\mathrm{V}$; (4) terdapat hubungan yang positif dan signifikan antara sikap sosial dan kecerdasan emosional terhadap hasil prestasi belajar siswa laki-laki dan perempuan kelas V.

\section{DAFTAR PUSTAKA}

Agus Efendi. 2005. Revolusi Kecerdasan Abad 21. Bandung: Alfabeta

Amaliyah. 2017. Hubungan Kecerdasan Intelektual dan Kecerdasan Emosional dengan Prestasi Belajar Siswa SD Muhammadiyah 29 Sunggal Deli Serdang. Jurnal ANSIRU. Nomor 1 Volume 1. Deli Serdang.

Caasmini. 2007. Emotional Parenting. Yogyakarta: Nuansa Aksara

Endah Susilowati. 2013. Kecerdasan Emosi Dengan Penyesuaian Sosial Pada Siswa Akselarasi Tingkat SMP. Jurnal Online Psikologi. Vol 
01 No. 01. Universitas Yogyakarta : Yogyakarta.

Fakih, M. (2006). Analisis Gender dan Transformasi Sosial. Yogyakarta : Pustaka Pelajar.

Goleman, Daniel. 2005. Emotional Intelligence (Kecerdasan Emosional). Penerjemah: $\mathrm{T}$. Hermaya. Jakarta: Gramedia Pustaka Utama.

Gusniwati, Mira. 2015. Pengaruh Kecerdasan Emosional dan Minat Belajar Terhadap Penguasaan Konsep Matematika Siswa SMAN di Kecamatan Kebon Jeruk. Jurnal Pendidikan. Program Studi Pendidikan Matematika, Fakultas Teknik, Matematika, dan IPA : Universitas Indraprasta PGRI.

Herlinda, Deska. Wasidi dan Illawaty Sulian. 2018. Hubungan Kecerdasan Emosi dengan Kemampuan Bersosialisasi Siswa di Lingkungan Sekolah Kelas VII SMP Negeri 03 Mukomuko. Jurnal Pendidikan. Volume 1. No. 3. Program Studi Bimbingan dan Konseling Fakultas Keguruan dan Ilmu Pendidikan : Universitas Bengkulu

Hlm. 101-113

Hurlock, Elizabeth B. 1978. Perkembangan Anak Jilid 1 . Penerjemah: Meitasari T. \& Muslichah Z. Jakarta: Gramedia Pustaka Utama.

Imam Ghozali. 2006. Aplikasi Analisis Multivariate dengn Program SPSS. Semarang: Badan Penerbit UNDIP.

Iman, Saeful. 2016. Hubungan Antara Kecerdasan Emosional dan Sikap Sosial dengan Prestasi Belajar Siswa Kelas V SD Se-Gugus II Depok Sleman. Skripsi. Fakultas Ilmu Pendidikan : Universitas Negeri Yogyakarta.

Izzaty, Rita Eka., dkk. 2013. Perkembangan Peserta Didik. UNYPress : Yogyakarta.
Martin, Anthony D. 2003. Emotional Quality Management. Penerjemah: Ary Ginanjar Agustian. Jakarta : Arga.

Menteri Pendidikan dan Kebudayaan. 2013. Peraturan Menteri Pendidikan dan Kebudayaan Nomor 64 Tahun 2013 tentang Standar Isi Pendidikan Dasar dan Menengah. Jakarta: Kepala Biro Hukum dan Organisasi Kementerian Pendidikan dan Kebudayaan.

Nurdin. 2009. Pengaruh kecerdasan emosional terhadap penyesuaian sosial siswa di sekolah. Jurnal Administrasi Pendidikan, IX, 1 86108.

Rahmawati, A. (2004). Persepsi Remaja tentang Konsep Maskulin dan Feminim dilihat dari Beberapa Latar Belakangnya. Skripsi pada Jurusan Psikologi Pendidikan dan Bimbingan UPI Bandung : Tidak diterbitkan.

Santrock, J.W. 2002. Perkembangan Anak Jilid 1. Penerjemah: Juda Achmad. Jakarta: Erlangga

Schneiders, Alexander A. 1964. Personal Adjustment and Mental Health. New York: Holt, Reinhart dan Winstons.

Setiadi, Hari. 2016. Pelaksanaan Penilaian Pada Kurikulum 2013. Jurnal Penelitian dan Evaluasi Pendidikan. Volume 20. No 2. Sekolah Pascasarjana UHAMKA Jakarta.

Siti Muflihah. 2004. Pengaruh Kecerdasan Emosional terhadap Penyesuaian Diri pada Remaja Kelas I dan II Madrasah Aliyah An-Nur Bululawang Malang. Skripsi. UIN Malang.

Slameto. 2003. Belajar dan Faktorfaktor Yang Mempengaruhunya. Jakarta: Rineka Cipta.

Stein, S.J. 2004. Ledakan EQ: 15 Prinsip Dasar Kecerdasan Emosional 


\section{Armo Armo, Akhmad Jazuli dan Tukiran Tanireja}

Meraih Sukses. Penerjemah: -. Bandung: Mizan Pustaka

Sugihartono, dkk.. 2007. Psikologi

Pendidikan. Yogyakarta: UNY

Press.

Sugiyono. 2005. Statistika Untuk

Penelitian. Bandung: Alfabeta.

Sugiyono. 2009. Metode Penelitian

Kuantitatif, Kualitatif dan $R \& D$.

Bandung: Alfabeta.

Sugiyono. 2013. Metode Penelitian

Pendidikan. Bandung: Alfabeta.

Suharsimi Arikunto. 2002. Prosedur

Penelitian. Jakarta: Rineka Cipta.

Sukmadinata, Nana Syaodih. 2004.

Landasan Psikologi Proses

Pendidikan. Bandung: PT Remaja

Rosdakarya.

Sunarto \& Hartono. 2006.

Perkembangan Peserta Didik.

Jakarta: Rineka Cipta
Sutrisno Hadi. 2004. Metodologi Research. Yogyakarta: Andi Offset.

Syamsu Yusuf. 2007. Psikologi Perkembangan Anak dan Remaja. Bandung: remaja Rosdakarya.

Thaib, Eva Nauli. 2013. Hubungan Antara Prestasi Belajar dengan Kecerdasan Emosional. Jurnal Pendidikan. VOL. XIII, NO. 2, 384-399. Fakultas Tarbiyah IAIN Ar-Raniry Banda Aceh.

Ulydays.com. 2018. Pengertian Kecerdasan Emosional Menurut Para Ahli. Di ambil tanggal 18 Juli 2019, pukul 14.45, dari https://www.google.co.id/amp/s/ul ydays.com/pengertian-kecerdasanemosional-menurut-para-ahli/amp/

W.A. Gerungan. 2004. Psikologi Sosial. Bandung: PT refika Aditama

Apendix

Aspek-aspek sikap sosial di atas dapat diturunkan ke dalam indikator- indikator penilaian sikap sosial berdasarkan Kurikulum 2013 antara lain:

\begin{tabular}{|c|c|c|}
\hline No & Sikap sosial & Indikator \\
\hline 1 & $\begin{array}{l}\text { Jujur adalah perilaku dapat } \\
\text { dipercaya dalam perkataan, } \\
\text { tindakan, dan pekerjaan. }\end{array}$ & $\begin{array}{ll} & \text { Tidak menyontek dalam mengerjakan ujian/ulangan } \\
\circ & \text { Tidak menjadi plagiat (mengambil/menyalin karya orang } \\
& \text { lain tanpa menyebutkan sumber) } \\
\circ & \text { Mengungkapkan perasaan apa adanya } \\
\circ & \text { Menyerahkan kepada yang berwenang barang yang } \\
\text { ditemukan } & \\
\circ & \text { Membuat laporan berdasarkan data atau informasi apa adanya } \\
\circ & \text { Mengakui kesalahan atau kekurangan yang dimiliki }\end{array}$ \\
\hline 2 & $\begin{array}{l}\text { Disiplin adalah tindakan } \\
\text { yang menunjukkan } \\
\text { perilaku tertib dan patuh } \\
\text { pada berbagai ketentuan } \\
\text { dan peraturan. }\end{array}$ & $\begin{array}{ll}\circ & \text { Datang tepat waktu } \\
\circ & \text { Patuh pada tata tertib atau aturan bersama/ sekolah } \\
\circ & \text { Mengerjakan/mengumpulkan tugas sesuai dengan waktu } \\
\text { yang ditentukan } \\
\circ \text { Mengikuti kaidah berbahasa tulis yang baik dan benar }\end{array}$ \\
\hline
\end{tabular}




\begin{tabular}{|c|c|c|}
\hline No & Sikap sosial & Indikator \\
\hline 3 & $\begin{array}{lr}\text { Tanggungjawab adalah } \\
\text { sikap dan perilaku } \\
\text { seseorang untuk } \\
\text { melaksanakan tugas dan } \\
\text { kewajibannya, yang } \\
\text { seharusnya dia lakukan, } \\
\text { terhadap diri sendiri, } \\
\text { masyarakat, lingkungan } \\
\text { (alam, sosial dan budaya), } \\
\text { negara dan Tuhan Yang } \\
\text { Maha Esa }\end{array}$ & $\begin{array}{ll} & \text { Melaksanakan tugas individu dengan baik } \\
\circ & \text { Menerima resiko dari tindakan yang dilakukan } \\
\circ & \text { Tidak menyalahkan/menuduh orang lain tanpa bukti yang } \\
\text { akurat } \\
\circ \text { Mengembalikan barang yang dipinjam } \\
\circ & \text { Mengakui dan meminta maaf atas kesalahan yang dilakukan } \\
\circ & \text { Menepati janji } \\
\circ & \text { Tidak menyalahkan orang lain untuk kesalahan tindakan kita } \\
\text { sendiri } \\
\text { Melaksanakan apa yang pernah dikatakan tanpa } \\
\text { disuruh/diminta }\end{array}$ \\
\hline 4 & $\begin{array}{l}\text { Toleransi adalah sikap dan } \\
\text { tindakan yang menghargai } \\
\text { keberagaman latar } \\
\text { belakang, pandangan, dan } \\
\text { keyakinan }\end{array}$ & $\begin{array}{l}\text { O Tidak mengganggu teman yang berbeda pendapat } \\
\circ \text { Menerima kesepakatan meskipun berbeda dengan } \\
\text { pendapatnya } \\
\circ \text { Dapat menerima kekurangan orang lain } \\
\circ \text { Dapat mememaafkan kesalahan orang lain } \\
\circ \text { Mampu dan mau bekerja sama dengan siapa pun yang } \\
\text { memiliki keberagaman latar belakang, pandangan, dan } \\
\text { keyakinan } \\
\text { Tidak memaksakan pendapat atau keyakinan diri pada orang } \\
\text { lain } \\
\text { Kesediaan untuk belajar dari (terbuka terhadap) keyakinan } \\
\text { dan gagasan orang lain agar dapat memahami orang lain lebih } \\
\text { baik } \\
\text { Terbuka terhadap atau kesediaan untuk menerima sesuatu } \\
\text { yang baru }\end{array}$ \\
\hline 5 & $\begin{array}{l}\text { Gotong royong adalah } \\
\text { bekerja bersama-sama } \\
\text { dengan orang lain untuk } \\
\text { mencapai tujuan bersama } \\
\text { dengan saling berbagi } \\
\text { tugas dan tolong menolong } \\
\text { secara ikhlas. }\end{array}$ & $\begin{array}{ll} & \text { Terlibat aktif dalam membersihkan kelas atau sekolah } \\
\circ & \text { Kesediaan melakukan tugas sesuai kesepakatan } \\
\circ & \text { Bersedia membantu orang lain tanpa mengharap imbalan } \\
\circ & \text { Aktif dalam kerja kelompok } \\
\circ & \text { Memusatkan perhatian pada tujuan kelompok } \\
\circ & \text { Tidak mendahulukan kepentingan pribadi } \\
\circ & \text { Mencari jalan untuk mengatasi perbedaan pendapat/pikiran } \\
\circ & \text { Mendorong orang lain untuk bekerja sama demi mencapai } \\
\text { tujuan bersama }\end{array}$ \\
\hline 6 & $\begin{array}{l}\text { Santun atau sopan adalah } \\
\text { sikap baik dalam pergaulan } \\
\text { baik dalam berbahasa } \\
\text { maupun bertingkah laku. } \\
\text { Norma kesantunan } \\
\text { bersifat relatif, artinya } \\
\text { yang dianggap baik/santun } \\
\text { pada tempat dan waktu } \\
\text { tertentu bisa berbeda pada } \\
\text { tempat dan waktu yang } \\
\text { lain. }\end{array}$ & $\begin{array}{ll}\circ & \text { Menghormati orang yang lebih tua. } \\
\circ & \text { Tidak berkata-kata kotor, kasar, dantakabur. } \\
\circ & \text { Tidak meludah di sembarang tempat. } \\
\circ & \text { Tidak menyela pembicaraan pada waktu yang tidak tepat } \\
\circ & \text { Mengucapkan terima kasih setelah menerima bantuan orang } \\
& \text { lain } \\
\circ & \text { Bersikap 3S (salam, senyum, sapa) } \\
\circ & \text { Meminta ijin ketika akan memasuki ruangan orang lain atau } \\
\text { menggunakan barang milik orang lain } \\
\circ \quad \begin{array}{l}\text { Memperlakukan orang lain sebagaimana diri sendiri ingin } \\
\text { diperlakukan }\end{array}\end{array}$ \\
\hline 7 & $\begin{array}{l}\text { Percaya diri adalah kondisi } \\
\text { mental atau psikologis } \\
\text { seseorang yang memberi } \\
\text { keyakinan kuat untuk } \\
\text { berbuat atau bertindak }\end{array}$ & $\begin{array}{ll}\circ & \text { Berpendapat atau melakukan kegiatan tanpa ragu-ragu. } \\
\circ & \text { Mampu membuat keputusan dengan cepat } \\
\circ & \text { Tidak mudah putus asa } \\
\circ & \text { Tidak canggung dalam bertindak } \\
\circ & \text { Berani presentasi di depan kelas } \\
\circ & \text { Berani berpendapat, bertanya, atau menjawab pertanyaan }\end{array}$ \\
\hline
\end{tabular}


Armo Armo, Akhmad Jazuli dan Tukiran Tanireja 